\title{
A Study of the Administration of Sports Councils and Their Effects on the Performance of Athletes in Nigeria
}

\author{
*Dr. (Mrs.) Igbokwe Philomena Ify \\ Department of Public Administration, Obafemi Awolowo University, Ile-Ife, Osun State, Nigeria. \\ Corresponding Author: Dr. (Mrs.) Igbokwe Philomena Ify
}

\begin{abstract}
The sports councils of various states were established to fulfill certain set objectives of organizing sporting activities ranging from foot-balling, hockey, cricket, swimming, boxing, wrestling etc, and to this end, the various governments put in place certain policies to enhance sporting activities. A study of the administration of sports councils and their effects on the performance of athletes is due to the fact that the state sports councils represent the formation root of sports, i.e. it handles grassroot sports, it discovers the talents and nurtures it, until it blossoms and comes into the limelight, in form of winning laurels. Often, when Nigeria teams engage in regional and international competitions, the performances of the teams have not always been encouraging, as they rarely win. At best, the teams collapse at semi-final. These lapses call into question the performance of the states sports councils whose responsibility is to administer sports in the states. Results showed that problems of inadequate funding, facilities, staffing and corruption have been the bane of the sports councils. These deficiencies in administrative and statutory functions and responsibility of the sports councils established and financed by governments have contributed to athletes weak performance in sports engagements.
\end{abstract} Keywords: Administration, sports, athletes, performance, Nigeria, sports councils, motivation.

\section{Introduction}

It is useful to begin by defining the concept of 'administration'. Administration simply defined means the organization and direction of persons in order to accomplish a specified end. 'Administration is the live wire of any establishment'. Administration must exist in any human organization set up for a defined purpose or objectives. Whether you think of the Church, the Army, a University, an industrial or business concern, a Sport Council or a purely social organization. There has to be administration because each one consists of human beings brought together in a hierarchical set-up, making use of tools, equipment, human and material resources, all in the quest to attain the set objectives for which the organization is established. Thus the bishop in the church, the field marshal in the army, the vice-chancellor in the University, the managing director or chairman of an industrial or business enterprise, each has under him a hierarchy of subordinates, each with functions and responsibilities assigned for the accomplishment of the overall objectives of the organization. This process requires planning, organization, command, co-ordination, and control. In short, administration connotes combination of human and material resources to achieve a set goal of any organisation.

The administrator's position within an establishment or organization is therefore strategic and pivotal. It is true to say that the place of administration has come to be clearly recognized in every sector of human endeavour, as being the keystone to the success and indeed to the very existence of the enterprise. Being concerned with the planning, co-ordination, supervision and control of the enterprise or establishment with which it is involved, it is no over-statement to declare that 'whatever may be the future, the science of administration will be an essential instrument of human welfare'. Indeed so significant is the importance of this instrument of human welfare that one can agree with the writers on administration who asserted that 'If our civilization breaks down, it will be mainly a breakdown of administration' and that 'the future of civilized government, and even of civilization itself, rests upon our ability to develop a science and philosophy and practice of administration competent to discharge the public functions of a civilized society'. Adebayo, A. (1980).

The term 'public administration' is commonly used to refer to both the activities concerned with the management of government business and the study of these activities. In other words it is used in two distinct senses, as practice and as knowledge. As practice, public administration is concerned with the activities that come directly under the government of any given society. It is sometimes referred to as government administration. This synonym helps to distinguish public administration from private administration. The latter refers to non-governmental administration. Adamolekun, L. (1982). Be that as it may, this study focuses on administration of Sports Councils in Southwestern Nigeria; government owned public parastatals otherwise 
known as State Owned Enterprises. The importance of sports and sporting activities to the health, physical, social and psychological development of human beings cannot be over emphasized. Participation in sports dates back to the ancient times, when it is on record that the first Olympic games took place in ancient Greece in the year 766 BC. Since then, different cultures and people have been taking part in sports, all over the world. In modern times, the administration of sports has attracted a lot of concern and attention because of the important roles that sports and sporting activities play in the lives of people. The sports council is a government parastatals or unit set up to control, organize and administer sports in the state or locality where it exists. It is like other parastatals or public enterprise established, financed and controlled by government that established it. Usually, a given sports council takes care of sports in all its ramifications within its area of jurisdiction. It is usually established by enactments, law or Act depending on its location (Federal or State jurisdiction).

Nigeria ordinarily is a country based on the principles of democracy and social justice. The Nigerian constitution contains provisions which establish the aspirations of the citizens in this regard, enunciates the appropriate political, economic and social objectives and stipulates the obligations of the Government and citizenry in the pursuit of those objectives. In particular, it is one of the cardinal provisions of the Nigerian constitution of 1979 that "the security and welfare of the people shall be the primary purpose of government" (Chapter II section 14(2).) and section 17 $7_{(1)}$ of 1999 CFRN. The fundamental social objectives which stand out clearly in the Nigerian constitution is the protection and advancement of the rights, security, dignity and welfare of the people.

All along, substantial resources have been committed by Government at both state and local government levels, to a wide range of programmes and projects and to the development of legislations intended to advance the pursuit of objectives in the sports development sector. Among the relevant programmes and projects are those in the areas of Youth and Sports.

However, some state governments, after a careful review of the development, past and present status, impact and potentials of the sports development sector, have come to the conclusion that much more needs to be done to streamline and strengthen the organization, resources and operation of the sector in order to maximize its contribution towards the attainment of the relevant state objectives.

Some of the responsibilities of sports councils and commission include the following:

i. To implement the government policies on sports to the entire citizens of the state;

ii. To encourage and facilitate the effective participation of teeming sportsmen and women, boys and girls in the state at national and international sporting competitions;

iii. To foster unity and healthy rivalry among the citizens of the state through well-organised sports competitions;

iv. To encourage specialization among sportsmen and women;

v. Provision and standardization of sports facilities and equipment in the state;

vi. To serve as the linking centre between the state and federal ministry of Youth and Sports, e.g. the national sports federation;

vii. To get all schools and colleges more actively involved in sports within and outside the state and to further enhance the health of students through their mass participation in sports, thereby creating a healthy learning environment and

viii. Enhancement of the image of the state, through achievements in sports e.g. Nigeria as a nation was raised to great heights in 1985, during the World Youth championship (football) and in 1994, Nigeria again, was brought to the limelight when she won the gold at the Olympic games.

However, it would appear that most of the time, the teams organized by some of these sports councils rarely get to the final stage of the competition and even if they do, they crash before reaching the gold medal stage, why this is so is the concern of this study. This study therefore attended to this end, it attempts to answer questions bothering on the assessment of sports administration that is, its successes and failures to compete effectively and to meet the world standard in soccer and other branches of sporting activities.

\section{Objective Of The Study}

The broad objective of this study is to assess the administration of sports councils and their effects on the performance of athletes.

The specific objectives are to:

i. examine the administrative role of the selected Sports Councils in Sporting activities in selected states of Southwestern Nigeria.

ii. identify the role of government in supporting the administration of the sports councils in the selected states of southwestern Nigeria; and

iii. highlight factors that are responsible for poor performance of athletes from the selected states in sporting tournaments in southwestern Nigeria. 


\section{Literature Review}

From the available literature reviewed, it has been established that an important step in becoming a successful sport administrator is gaining an in-depth awareness of sport as an important cultural activity that permeates our society and influences both institutions and individuals in multiplicity of ways. In order to understand the complex dynamics of how and why people participate in sport and physical activity, you must have knowledge about not only individual behaviour (e.g., psychological aspects such as motivation) but also the social context in which that behaviour occurs. Over the past three and a half decades, the scientific study of the social context of sport has been at the center of an academic discipline called sport sociology.

According to Eldon Snyder (1990), activities such as basketball, football, tennis, and golf are sports. However, Snyder also pointed out that a wide range of other kinds of physical activities are also considered "sport" such activities could include walking, fishing, and hiking. What is clear from these examples is that there exists a continuum of physical activity ranging from informal, play like activity in a leisure setting, to the highly competitive, pressure-filled world of professional sport.

Given that sport is such a significant part of contemporary U.S. society, it is not surprising that scholars would be interested in studying its scope and impact (Coakley, 2001). Beginning in the mid - 1960's, researchers from academic fields such as sociology and kinesiology tried to do more than define sport and various aspects of physical activity - they also began to develop a scientific body of knowledge related to the nature and significance of sport. This effort led to the emergence of a new academic discipline called sport sociology. According to Jay Coakley, sport sociology could be defined as the "sub-discipline of sociology that studies sports as parts of social and cultural life".

An underlying assumption of sport sociology is that sport is a highly significant institution of the same magnitude as the economy, the family, the educational system, and the political structure. A fundamental goal of sport sociology is to describe the complex dynamics surrounding patterns of participation (e.g., the number of girls versus the number of boys involved in youth sports) and social concerns (e.g. an overemphasis on winning) that made up this important and all-pervasive institution (Nixon and Frey 1996). It is important to keep in mind, however, that sport sociologists do far more than describe sport involvement by, for example, gathering data on how many people participate on an annual basis. Sport sociologists are ultimately concerned with understanding the social context in which this participation occurs, as well as the meaning of sport as a highly influential social, political, and economic institution (Siedentop, 1990).

\section{Methodology}

The study was designed to investigate the administration of sports councils in selected states of southwestern Nigeria, Lagos, Ondo and Oyo states, using ex-post-factor design. Ex-post-factor design is a research in which the researcher has no control over the independent variables. In this case, the phenomenon (administrative shortcomings of the sports councils) which the researcher was investigating, had already occurred hence, the researcher was just finding the causes of the phenomenon. The researcher investigated the causes, techniques and procedures used to manage the observed administrative shortcomings of the councils.

To this end, questionnaire was drawn to contain a number of items on sports administration. The respondents were asked to indicate major variables that were responsible for the causes of administrative shortcomings of the councils studied. They were also made to respond to those items of the questionnaire that were used to resolve the administrative shortcomings of the councils and also to identify some motivating factors responsible for the performance of the sports councils. Furthermore, the respondents were asked to identify some of the effects of this motivation on the performance and attainment of goals set for the councils.

\section{Study Population}

The study population comprised workers (both Administrative and non administrative) of three states sports councils in Lagos, Ondo and Oyo. The total population of staff of the selected councils stood at 615 that is (Lagos - 198, Ondo - 297 and Oyo - 120).

\section{Sampling Procedure}

A sample is a subset of research population, selecting a representative group from the population. This sample was dealt with and from it, conclusions were drawn relating to the universe i.e. for the whole material from which the sample was taken. Again, it may be good to consider the condition under which an investigator conducts a study and the entire study population. One of the guiding principles is that, if the entire study population is small, the whole study population might be selected for the study.

At the end of the study the entire population of staff of the three states sports council was fairly large and to this end, a forty percent (40\%) sample of the total population of the staff of the selected councils (Grade level $06-11$, middle level staff) and (Grade level $12-15$, management staff) were stratified, while the permanent secretary, and councils members were interviewed in each of the selected sports councils in the 
southwestern Nigeria. Therefore, the sample size of the study was 246 officials, drawn through the following sampling procedure. Purposive sampling was used because the study addresses administration of sports councils and the management staff are in charge. To that extent, it is believed that purposive sampling procedure is more relevant for the study. This was supported by a random selection of sports athletes and supporters clubs for focus group discussion.

\section{Instruments of Collecting Data}

Primary data were collected through questionnaire, interview and participant observation methods. In order to complement the data collected, the athletes and leaders of the supporters clubs were interviewed as external assessors of the administration of the sports councils.

The secondary data were sourced from Journals, Sporting magazines, sporting records, in the sports councils and government gazettes. Consequently, questionnaire was beefed up with interviews that were conducted with the following political functionaries as decision makers of the councils. They are -3 general managers, -3 chairmen, -9 directors and 15 heads of departments of the councils. Furthermore, interview was extended to the permanent secretary, Ministry of Youth, Sports and Social Development of each of the states to gather information on administration of sports councils in the state as administrative overseers of the councils.

\section{Validity and Reliability of Research Instruments}

The validation of any instrument means measurement of what it purports to measure. That is, the instrument must elicit information that is relevant to the research. If it fails to do this, then the instrument cannot be regarded as 'valid'. To ensure the validity of the questionnaire, a pretest of research instrument was carried out as a preliminary enquiry before a full scale field survey was conducted.

The research instruments of this study were the Questionnaire, Interview schedules and Focus Group Discussion (FGD). The instruments were first of all pre-tested on a handful of athletes, spectators and supporters club with a view to determining the reliability and validity of the research methods and instruments of gathering data for the study. Furthermore, the result of the pretest was positive meaning that the instrument were adjudged suitable for the study as the questions that informed the questionnaire, oral interview and FGD used were derivates of the objectives of the study and perhaps that made the pretest reliable and acceptable.

\section{Methods of Analysis of Data}

The data collected were analysed through the use of descriptive and inferential statistics. Such as frequency distribution and percentage analysis. In the analysis, those who agreed and the strongly agreed respondents were merged together, while the disagreed and strongly disagreed respondents were also merged together. The analysis now had agreed and disagreed respondents. This was done purely to ease the percentage calculations. The responses to the questionnaire were coded and analysed using simple percentages.

\section{Findings of Study}

Data collected were presented in tables and analysed using, inferential and descriptive statistics. The use of simple percentages was informed by the intention to determine the relative standing of the different categories of the attributes studied. In other words, it was aimed at demonstrating the frequency distribution of variables dealt with in the study. However, in order to determine the percentages, the frequency of each category in the table was divided by the total number of frequencies and then the quotient was multiplied by 100 . This then was applied directly to the data collected as it affects the concerned variables.

Table 1.1: Frequency Distribution by Age of The Respondents at the Lagos, Ondo and Oyo States Sports

\begin{tabular}{|l|l|l|l|l|l|l|}
\hline Value (in years) & \multicolumn{3}{|c|}{ Frequency } & \multicolumn{4}{c|}{ Percentage \% } \\
\hline & Lagos & Ondo & Oyo & Lagos & Ondo & Oyo \\
\hline $0-20$ yrs & - & - & - & - & - & - \\
$21-30 y r s$ & 10 & 14 & 15 & 13.3 & 14.3 & 17.0 \\
$31-40 y r s$ & 14 & 22 & 25 & 18.7 & 22.4 & 28.0 \\
$41-50 y r s$ & 36 & 42 & 35 & 48.0 & 42.9 & 39.0 \\
$51-60 y r s$ & 12 & 19 & 10 & 16.0 & 19.4 & 11.0 \\
61and above & 3 & 1 & 5 & 4.0 & 1.0 & 5.0 \\
\hline Total & $\mathbf{7 5}$ & $\mathbf{9 8}$ & $\mathbf{9 0}$ & $\mathbf{1 0 0 . 0}$ & $\mathbf{1 0 0 . 0}$ & $\mathbf{1 0 0 . 0}$ \\
\hline
\end{tabular}

Source: Author's Fieldwork

The age distribution of the respondents at the Lagos State Sports Council shows that the ages of the majority of the respondents fell between $31-50$ years, implying that the manpower is youthful, meaning that the goals of the sports council would be better achieved. 
The staff whose age ranged from 21 - 30 years constituted $13.3 \%$ of the respondents while, those who were $31-40,41-50,51-60$ and 61 years old and above accounted for $18.7 \%, 48.0 \%, 16.0 \%$, and $4 \%$ respectively.

At the Ondo state Sports councils. It shows that staff whose age ranges from $21-30$ years constitute $14.3 \%$, while those who were $31-40,41-50,51-60$ and 61 years old and above accounted for $22.4 \%, 42.9 \%$, $19.14 \%$ and $1.0 \%$ respectively.

From this table, the distribution shows that the staff at the Ondo state Sports council whose ages ranged from 31-50years accounted for more than 50\% of the work force. Therefore one can comfortably say that majority of the staff at the Ondo state sports council are middle aged and experienced workers who could achieve the goals of the sports council.

As shown in table 1.1, the age distribution of the respondents in the Oyo State Sports Council, followed the same pattern as that of the Lagos State Sports Council. The ages of the majority of the respondents fell between $31-50$ years, which is a positive sign, by implication as regards performance age-wise.

Table 1.2: Frequency Distribution by Sex of The Respondents Among workers at the Lagos, Ondo and Oyo States Sports Councils

\begin{tabular}{|l|l|l|l|l|l|l|}
\hline Value (in years) & \multicolumn{3}{|c|}{ Frequency } & \multicolumn{3}{c|}{ Percentage \% } \\
\hline & Lagos & Ondo & Oyo & Lagos & Ondo & Oyo \\
\hline Male & 56 & 72 & 56 & 75 & 73 & 62 \\
Female & 19 & 26 & 44 & 25 & 27 & 38 \\
\hline Total & $\mathbf{7 5}$ & $\mathbf{9 8}$ & $\mathbf{9 0}$ & $\mathbf{1 0 0 . 0}$ & $\mathbf{1 0 0 . 0}$ & $\mathbf{1 0 0 . 0}$ \\
\hline
\end{tabular}

Source: Author's Fieldwork

As presented Table 1.2, out of the 75 respondents at the Lagos State Sports Council, 56 were males, while 19 were females, indicating that there were more male workers than female workers in the Lagos State Sports Council. At Ondo State, out of the ninety-eight respondents, 72 of them were males while, 26 of them were females. These figures represented $73 \%$ and $27 \%$ respectively. Based on this distribution, it is observed that the Ondo State Sports Council is dominated by male staff.

Table 1.2 also shows the sex distribution of the respondents that took part in the study at the Oyo State Sports Council. Out of the 90 respondents, 56 of them were males, while 44 were females as represented by these figures $62 \%$ and $38 \%$. From the above analysis, it could be said that majority of the workers in the Oyo State Sports Council are males.

Table 1.3 Frequency Distribution by Qualifications of Respondents among the staff at the Ondo State Sports Council

\begin{tabular}{|l|l|l|}
\hline Value & Frequency & Percentage \% \\
\hline Ph.D. & 08 & 08.4 \\
MA/MSC./MBA & 69 & 70.2 \\
BA, B.SC, B.ED, HND & 21 & 21.4 \\
OND/NCE & - & \\
SSCE, GCE & - & \\
MOD/PRY.SIX & - & \\
\hline Total & $\mathbf{9 8}$ & $\mathbf{1 0 0 . 0}$ \\
\hline
\end{tabular}

Source: Author's Fieldwork

The figure in Table 1.3 shows the frequency distribution of respondents by educational qualifications of the Ondo State Sports Council. Eight were Ph.D holders (8.4\%), 69(70.2\%) had Masters Degree, while 21(21.4\%) had first degree. This is an indication that the Ondo State Sports Council had well-qualified administrative staff.

Table 1.4: Frequency Distribution by Qualifications of the Respondents at the Lagos State Sports Council

\begin{tabular}{|l|l|l|}
\hline Value & Frequency & Percentage \% \\
\hline Ph.D. & 7 & 9.0 \\
MA/MSC./MBA & 35 & 47.0 \\
BA, B.SC, B.ED, HND & 33 & 44.0 \\
OND/NCE & - & \\
SSCE, GCE & - & \\
MOD/PRY.SIX & - & $\mathbf{1 0 0 . 0}$ \\
\hline Total & $\mathbf{7 5}$ & \\
\hline
\end{tabular}

Source: Author's Fieldwork 
In Table 1.4, the frequency distribution by qualification of the respondents at the Lagos State Sports Council shows clearly that among the administrative staff, the holders of first degree and masters degree were in the majority and that is to say the Lagos State Sports Council has qualified administrative staff.

Table 1.5: Frequency Distribution by Qualification of the Respondents (Oyo State)

\begin{tabular}{|l|l|l|}
\hline Value & Frequency & Percentage \% \\
\hline Ph.D. & 1 & 1.0 \\
MA/MSC./MBA & 18 & 20.0 \\
BA, B.SC, B.ED & 22 & 27.0 \\
HND & 18 & 20.0 \\
OND/NCE & 31 & 33.0 \\
SSCE, GCE & - & - \\
MOD/PRY.SIX & - & - \\
\hline Total & $\mathbf{9 0}$ & $\mathbf{1 0 0 . 0}$ \\
\hline
\end{tabular}

\section{Source: Author's Fieldwork}

Table 1.5 shows the frequency distribution of the staff of the Oyo State Sports Council. Judging from the number of administrative staff with first degrees and OND/NCE Certificates, it could be said that the Oyo State Sports Council has a viable staff strength who could fulfill the aspirations of the Sports Council.

Table 1.6: Assessment of the Administrative Role(s) of the Lagos State Sports Council

\begin{tabular}{|c|c|c|c|c|c|}
\hline & Administrative Role(s) & Agree & $\%$ & Disagree & $\%$ \\
\hline 1 & $\begin{array}{l}\text { The Sports Council interprets the Government policies on sports to } \\
\text { the entire citizens of the state. }\end{array}$ & 55 & 73 & 30 & 27 \\
\hline 2 & $\begin{array}{l}\text { The Sports Council encourages and facilitates the effective } \\
\text { participation of Athletes in the State at National and international } \\
\text { levels. }\end{array}$ & 68 & 90 & 7 & 10 \\
\hline 3 & $\begin{array}{l}\text { The Sports Council forges unity and Healthy rivalry among the } \\
\text { citizens of the state through well-organised sports competitions. }\end{array}$ & 65 & 7 & 10 & 13 \\
\hline 4 & $\begin{array}{l}\text { The Sports Council serves as linking between the state and national } \\
\text { sports commission }\end{array}$ & 70 & 93 & 5 & 7 \\
\hline 5 & $\begin{array}{l}\text { The Sports Council gets all schools and colleges more actively } \\
\text { involved in sporting activities within and outside the state. }\end{array}$ & 60 & 80 & 15 & 20 \\
\hline 6 & $\begin{array}{l}\text { The Sports Council enhances the health of students through their } \\
\text { mass participation in Sports thereby creating a healthy learning } \\
\text { environment }\end{array}$ & 45 & 60 & 40 & 42 \\
\hline 7 & $\begin{array}{l}\text { The major area of constraint in the councils operation is the lack of } \\
\text { sports equipment and outfits. }\end{array}$ & 50 & 66 & 25 & 34 \\
\hline 8 & $\begin{array}{l}\text { The provision of these equipment would enable the athletes to train, } \\
\text { compete and win laurels for the state }\end{array}$ & 55 & 73 & 20 & 27 \\
\hline 9 & There should be more training facilities in place for the athletes & 68 & 90 & 7 & 10 \\
\hline 10 & $\begin{array}{l}\text { More laurels should be brought home to the state to justify the money } \\
\text { and time spent by the Government }\end{array}$ & 75 & 100 & - & - \\
\hline
\end{tabular}

\section{Source: Author's Fieldwork}

Table 1.7: Assessment of the Administrative Role(s) of the Ondo State Sports Council

\begin{tabular}{|l|l|l|l|l|l|}
\hline & Administrative Role(s) & Agree & $\mathbf{\%}$ & Disagree & \% \\
\hline 1 & $\begin{array}{l}\text { The Sports Council interprets the Government policies on sports to } \\
\text { the entire citizens of the state. }\end{array}$ & 56 & 57 & 43 \\
\hline 2 & $\begin{array}{l}\text { The Sports Council encourages and facilitates the effective } \\
\text { participation of Athletes in the State at National and international } \\
\text { levels. }\end{array}$ & 90 & 91 & 5 & 9 \\
\hline 3 & $\begin{array}{l}\text { The Sports Council forges unity and Healthy rivalry among the } \\
\text { citizens of the state through well-organised sports competitions. }\end{array}$ & 85 & 86 & 13 & 14 \\
\hline 4 & $\begin{array}{l}\text { The Sports Council serves as linking between the state and national } \\
\text { sports commission }\end{array}$ & 78 & 80 & 20 & 20 \\
\hline 5 & $\begin{array}{l}\text { The Sports Council gets all schools and colleges more actively } \\
\text { involved in sporting activities within and outside the state. }\end{array}$ & 76 & 78 & 22 \\
\hline 6 & $\begin{array}{l}\text { The Sports Council enhances the health of students through their } \\
\text { mass participation in Sports thereby creating a healthy learning } \\
\text { environment }\end{array}$ & 45 & 46 & 53 & 54 \\
\hline 7 & $\begin{array}{l}\text { The major area of constraint in the councils operation is the lack of } \\
\text { sports equipment and outfits. }\end{array}$ & 85 & 86 & 13 & 14 \\
\hline 8 & $\begin{array}{l}\text { The provision of these equipment would enable the athletes to train, } \\
\text { compete and win laurels for the state }\end{array}$ & 90 & 91 & 5 & 9 \\
\hline 9 & There should be more training facilities in place for the athletes & 95 & 96 & 3 & 4 \\
\hline 10 & $\begin{array}{l}\text { More laurels should be brought home to the state to justify the money } \\
\text { and time spent by the Government }\end{array}$ & 98 & 100 & - & - \\
\hline
\end{tabular}


Table 1.8: Assessment of the Administrative Role(s) of the Lagos State Sports Council

\begin{tabular}{|c|c|c|c|c|c|}
\hline & Administrative Role(s) & Agree & $\%$ & Disagree & $\%$ \\
\hline 1 & $\begin{array}{l}\text { The Sports Council interprets the Government policies on sports to } \\
\text { the entire citizens of the state. }\end{array}$ & 52 & 58 & 38 & 42 \\
\hline 2 & $\begin{array}{l}\text { The Sports Council encourages and facilitates the effective } \\
\text { participation of Athletes in the State at National and international } \\
\text { levels. }\end{array}$ & 80 & 89 & 10 & 11 \\
\hline 3 & $\begin{array}{l}\text { The Sports Council forges unity and Healthy rivalry among the } \\
\text { citizens of the state through well-organised sports competitions. }\end{array}$ & 70 & 78 & 20 & 22 \\
\hline 4 & $\begin{array}{l}\text { The Sports Council serves as linking between the state and national } \\
\text { sports commission }\end{array}$ & 80 & 89 & 10 & 11 \\
\hline 5 & $\begin{array}{l}\text { The Sports Council gets all schools and colleges more actively } \\
\text { involved in sporting activities within and outside the state. }\end{array}$ & 74 & 82 & 16 & 18 \\
\hline 6 & $\begin{array}{l}\text { The Sports Council enhances the health of students through their } \\
\text { mass participation in Sports thereby creating a healthy learning } \\
\text { environment }\end{array}$ & 42 & 47 & 48 & 53 \\
\hline 7 & $\begin{array}{l}\text { The major area of constraint in the councils operation is the lack of } \\
\text { sports equipment and outfits. }\end{array}$ & 76 & 84 & 14 & 16 \\
\hline 8 & $\begin{array}{l}\text { The provision of these equipment would enable the athletes to train, } \\
\text { compete and win laurels for the state }\end{array}$ & 78 & 86 & 12 & 14 \\
\hline 9 & There should be more training facilities in place for the athletes & 85 & 96 & 4 & 4 \\
\hline 10 & $\begin{array}{l}\text { More laurels should be brought home to the state to justify the money } \\
\text { and time spent by the Government }\end{array}$ & 90 & 100 & - & - \\
\hline
\end{tabular}

\section{Source: Author's Fieldwork}

Table 1.6, 1.7 and 4.8 show that, the sport councils interpret the government policies on sports to the entire citizens of the state. Here we see that the percentages $73 \%, 57 \%$ and 58 respectively, explains why it is difficult sometimes for the citizens to understand the role(s) the sports council plays in the state as regards sports participation.

\section{Athletes}

Based on the face-to-face interview with the athletes, it was agreed that the Sports Councils encourage and facilitate the effective participation of athletes in the state at National and International levels. There was also a consensus on the following; that there is a need for government to encourage them, meaning to motivate them. If Government employs some outstanding athletes in sports to enhance the performance of the locally discovered Athletes, not just giving them cash gifts but doing things that are lasting.

There are training facilities but there is need for improvement, since the provision of these equipment and facilities would enable the athletes to train, compete and win laurels for the state. Also the Athletes showed a lot of concern for their health and insists that if properly taken care of, then the issue of motivation would not be rated highly. Health services for athletes involve continuous medical attention, sound policies and procedures, and the availability of qualified personnel. A close working relationship should exist among coaches, trainers, athletic directors, administrators and medical service representatives in order to adequately protect athletes from injury and harm. Medical supervision of athletes can be improved if the administration, physical educators, coaches, and trainers make this priority. Frequently, coaches lack medical training, and they feel that too much supervision from doctors and nurses will hurt their team's won-lost record. A philosophy of medical supervision must be adopted that places the individual athlete first and enables him or her to have the best possible medical attention. Again, elaborate training rooms and equipment are not essential in athletic programs. Adequate health supervision of sports is essential for the following factors:

1. the physical, physiological, and psychological demands of competition.

2. the problem of treatment and rehabilitation involved in athletic injuries.

3. the increased possibility of infectious diseases caused by lowered resistance, and

4. the close relationship between physical activity and disease and injury.

\section{Supporters Club}

From the face-to-face interview with the leaders of the supporters clubs, it was gathered that there is a link between the sports councils and the supporters club, that they contribute both morally and financially to the activities of the councils and have some influence on the performance of the athletes. They assessed the performance of the sports councils through their achievements, i.e. if they win in tournaments, then they are rated as good and bad if they do otherwise. Considering the vast needs of our societies and the need for every individual to benefit from any plans made in this regard and considering the limitation of the Nigerian government in financing sporting activities and institutions, there is a need for assistance from other bodies to supplement the efforts of the government. It is in this regard that the services of the supporters club need to be encouraged seriously in complementing the services provided by Government if sports development is to reach 
the grassroots. The activities of the supporters clubs are even of greater importance now that there seems to be a breakdown of those traditional institutions and community organizations that formerly catered for sports due to changes in the economic and political systems. The supporters club complements the efforts of the sports councils and that of the government through the selfless service rendered to the community by motivating the athletes towards attainment of success in their tournaments.

\section{Management}

The interview conducted with the staff revealed the means with which the sports councils interpret the government policies on sports to the entire citizens of the state.

Through the use of the media i.e. television, radio, prints and coaches. They explained how they reach out to the entire citizenry, in doing this, there are constraints encountered, i.e. finance and the issue of terrains, this brings to view transportation, to enhance effective training and mobility of Athletes and officials to venues and to the people at the grassroots, the council is faced with a lot of difficulty, though not so to a large extent for the Lagos state sports council but heavily for their Ondo counterparts. Therefore, for effective promotion of sports from grass-root to national and international levels, the state government must ensure provision of vehicles, mobility to enhance efficiency.

One of the major objectives of the sports councils is to promote sports at all levels and to spread the principle of mass participation to every nook and cranny of the state. To achieve this basic objective, there is the need to have the right caliber of personnel to cover all the local governments of the state.

There was consensus on the need to recruit coaches, performers and sports organizers, to all the Local Government headquarters to enable them reach the local level and discover the hidden talents. The facilities department too is not less affected. The maintenance of the existing facilities at the Headquarters cannot be over emphasized.

Physical plants require careful planning, and specialists in this area of architecture must be consulted. Administrators and other personnel should participate in planning new facilities and be knowledgeable about their structure and functions. Trends and innovative structural concepts should be thoroughly examined in order to provide a healthful and efficient physical plant.

The facility is a major consideration in most administrative, athletic and recreational programmes. New architectural ideas are being introduced and new concepts developed in order to have a more economical and functional plant. Some building concepts include convertibility, for example: rearranging interiors by using elements such as movable walls and partitions and using such areas as the gymnasium and amphitheatre for a variety of activities such as basketball, and baseball. Such versality is needed in order to accommodate a number of different activities so that small and large group instruction and independent study spaces may be provided. This flexibility also ensures such important functions as team teaching and proper installation and use of electronic aids.

Another area of concern for the management is issue of understaffing as the three councils investigated confirmed their understaffing position hence the need for increase in their staff strength. The councils are still striving hard to cope with its numerous sporting programmes with very few hands available. The effect of this is that the staff population is grossly inadequate to effectively man the 25 sports associations and to enable them cover every nook and cranny of the state for the discovery of new talented boys and girls.

The fund from the Government proved to be in adequate, considering the magnitude of the sporting activities involved. This inadequacy translates into non-performance on the part of the councils, which reflects on the results of the activities organized by the council, i.e. sports festivals, local and national competitions. The expenses of the council usually covers camping competition and provision of consumable sport equipment.

It must be mentioned that government approved budgets for the councils recurrent expenditure only gets to them partly, which affects their planning. The major area of constraint in the councils operation is the problem of facilities, infact both the management and athletes agreed that if given the right facilities, that the issue of motivation would have been dealt with squarely, because without the provision of equipment for the training of athletes, it would be difficult to excel and move out to meet the international standard.

Another area of concern for the council is that one of the major objectives of the councils is to promote to all levels and to spread the principle of mass participation to every nook and cranny of the state. To achieve this basic objective, there is need to have the right calibre of personnel to cover all the local governments of the states. There is need to recruit more coaches, performers and sports organizers, to man all the local government Headquarters to enable them reach the local level and discover the hidden talents.

The facilities department too is no less affected. The maintenance of the existing facilities at the headquarters cannot be over emphasized, the councils need the right maintenance outfits. Another objective of the council is to target all schools and colleges to be more actively involved in sports within and outside the state and to further enhance the health of students through their mass participation in sports thereby creating a healthy learning environment. In order to achieve this set objective, the councils advised that the states should 
revert to the old system whereby the total control of sports in schools could be handled by the sports council while the Ministry of Education serves as co-ordinator instead of the present situation where the ministry is taking over the functions of the sports councils. The Ministry of Education and Sports councils are partners in progress. The councils are under-staffed, under funded with little or no facilities. In spite of these inadequacies the States Sports Councils are still striving to achieve their set objectives.

\section{Competitions}

Sport goes beyond being a measure of athletic excellence, winning of trophies, medals and fame. Sports is an integral thread in the fabrics of society and it enriches qualities of life and life satisfaction. Most of us have favourite sports we play or follow with passion, be it soccer, cycling, athletics etc. Sports teach us about honest endeavor, commitment and fair play. The most honourable individuals are those who have competence in competition and adhere to its finest principles. True winners are those who achieve their goals through talent, skill training, motivation and rising to all the challenges their sport might present.

\section{Conclusion}

Over the years, the fund from the Government has proved to be inadequate, considering the magnitude of the sporting activities being organized by the sports council. This inadequacy has affected the sports festivals, local and national competitions. Expenses in these areas should normally cover camping, competition and provision of consumable sport equipment.

The major area of constraint in the council's operation is the inadequate modern sport facilities and equipment. It seems obvious that, without the provision of equipment for the training of state athletes, it would be difficult to compete favourably with other sister states in the federation.

Therefore, the provision of these equipment would enable the athletes to train, compete and win laurels for the state.

We can, then, look at motivation as involving a chain reaction, starting out with felt needs, resulting in wants or goals sought, which give rise to tensions (that is unfulfilled desires), then causing action toward achieving goals, and finally satisfying wants.

Therefore, the administrators at the sports councils will produce better athletes, if they are better motivated; if they are given more funds, better equipment and facilities and if more coaches are employed, trained and retrained at regular basis, then this will in effect reflect in the performance of the athletes. The athletes on their own part would also perform better if they are well motivated; if they are provided with the right training facilities, paid better allowances, camped for a reasonably length of time before any competition, have the right coaching staff, given scholarships to study and job opportunities for exceptional athletes, then, the chain will be complete on a positive note.

\section{Recommendations}

After a thorough study of the administration of sports councils and their effects on the performances of athletes in Lagos, Ondo and Oyo states, the following recommendations were made:

(a) That Government should give more support to the sport sector in form of putting facilities in place and providing more funds for the sports councils.

(b) Considering the financial limitation of the government, it has come to be accepted that there is a need for assistance from other bodies to supplement the efforts of government. It is in this regard that the services of the voluntary agencies/organizations need to be encouraged seriously in complementing the services provided by the Government if sports development is to reach the grass-roots.

(c) There is need for proper motivation of athletes; they should be motivated with things that would encourage up coming athletes. i.e. employ some outstanding athletes in some sports, as this will boost the performances of the locally discovered athletes.

(d) The discovered athletes in all the 25 sporting Associations should be given the opportunity to attend National organized competitions. This will not only improve the performances of the state athletes but it will enhance their being selected to represent Nigeria in team or individual sporting events.

From the findings of this study it has been discovered that in as much as funding has a far reaching role to play in the achievements of athletes, the administrators at the councils have greater role to play in planning and organizing. It is on record that in National Sports Festivals, Lagos state has the best track record amongst the other two states, Ondo and Oyo.

The success of Lagos can be attributed to some factors; good administration, being the former capital and the support they get from sponsorship; companies and voluntary agencies and organizations. In view of this external supports, athletes are better paid, camped for longer duration and given more incentives; which in turn brings out the best in them. 
Ondo being an up coming state, has not done badly; the athletes are trying very hard considering the fact that they don't have the sort of facilities that Lagos and Oyo states have. The government of Ondo state is very supportive of the sports sector and they have administrators that are very committed to the development of sports. Oyo state being an old state and the zonal headquarters has relatively better facilities but the political climate of the state has a negative influence on the sports council. From the records in the past, Oyo athletes used to be amongst the best, but over a long period of time, their performance took a downward toll due to politicization of sporting activities.

Therefore, for effective promotion of sports from grass-root to National and International levels, the athletes, sports councils and the Government must work together as partners in progress in order to raise the tone of Nigeria in international and regional sporting tornaments.

\section{BOOKS}

\section{References}

[1] Adamolekun, L. (1982): Public Administrations: A Nigeria and Comparative Perspective, London: Longman Group Limited.

[2] Adebayo, A. (1980): Principles and Practice of Public Administration in Nigeria, Ibadan: Spectrum Books Limited.

[3] Barnard, C.I. (1938) The functions of the Executive (Cambridge, mass: Harvard University Press, p. 84.

[4] Bereleson B. and G.A. Steiner, Human Behavior: An Inventory of Scientific Findings (New York: Harcourt, Brace \& World, Inc., 1964) p. 240.

[5] Butler (1959) Introduction to Community recreation. New York: McGraw-Hill

[6] Cahill \& A.J. Peal (Eds) Intensive participation in children sport (pp. 77- 94)

[7] Coakley (2001) Sport in Society: Issues and Controversies ( $7^{\text {th }}$ Ed.) St. Louis Mosby.

[8] Coakley J.J. (1998) Social Dimensions of Intensive training and participation in Youth Sports. In B.R. Cahcle \& A. J. Peal (Eds). Intensive participation in children sport (pp.77 - 94).

[9] Coakley J.J. (1998) Sport in Society: Issues \& Controversies (6 ${ }^{\text {th }}$ ed.) Boston. WCB McGraw - Hill.

[10] Coakley, J.J. (1994) Sport in Society: Issues and controversies. Saint Lousi: C.V. Mosby.

[11] Duron (1990) When corporate fitness programs benefit the Youth and the community. Perspective, November 1990, P. 12-14.

[12] Edginton and Williams (1985) Productive Management of Leisure Service organizations. pg. 2

[13] Godby (1978) Recreation, Park and leisure services. Philadelphia. Pg 8

[14] Goodale and Godby (1988) The evolution of leisure London Venture.

[15] Greendorfer, S. (2001). Gander role stereotypes and early childhood socialization. In G.L. Cohen (Ed).

[16] Griffiths, D.E. and Urwick, L. editors: Papers on the Science of Administration, New York 2005, Institute of Public Administration.

[17] Guttmann, A (1978) From Ritual to Record. New York. Columbia University Press.

[18] Iso Ahola (1980) The Social Psychology of Leisure and recreation: Iowa C. Brown Co.pg 8.

[19] McPherson, B.D., Curtis, J.E. \& Loy, J.W. (1989). The Social Significance of Sport. Champaign, IL: Human Kinetics.

[20] Nixon, H.L., \& Fray, J.H. (1996). A Sociology of Sport Belmont, CA: Wadsworth

[21] Pavett and Whitney (1990) Exercise makes employees work better. Human Resources Magazine, December 1990.

[22] Siedentop, D. (1990) Introduction to Physical education, fitness and sport. Mountain view, CA: Mayfield.

[23] Snyder and Spreitzer (1989). Social aspects of Sport; Englewood Cliffs, NJ: Prentice Hall.

[24] Snyder, E. (1990). Sociology of Sport in J.B. Parks \& R.K. Zanger (Eds.) Sport and fitness management (pp. 213-222). Champaign, IL: Human Kinetics.

[25] Torkildsen (1992) Leisure and recreation management London: E.F.N. Spon. Pg 15.

[26] Volger, C.C. \& Schwarts, S.E. (1993). The Sociology of Sport: an Introduction - Englewood Cliffs: prentice-Hall.

\section{JOURNAL ARTICLES}

Botha (1978) Sport in Perspectief Pretoria: Universieteit van pretoria Series No. 56.

Loy's (1968) The Nature of Sport: A definitional effort. Quest, 10, 1-15.

Marion, L.J., (1971) South-Eastern Lousisana University and Physical Educators 28:39, 1971.

Scholtz (1983) S.A. Journal for Research in Sport, Physical Education and Recreation. Pg. 3.

Wohl, A. (1979) Sport and Social Development. International Review of Sport Sociology, 14 (3-4), P. 5-18.

\section{NEWSPAPER AND MAGAZINES}

\begin{tabular}{|c|c|}
\hline The Guardian & Tuesday, January 20, 1998 \\
\hline The Guardian & Tuesday, June 22, 1999 \\
\hline The Nigerian Tribune - & October 31,2004 \\
\hline The Guardian & September 10, 2004 \\
\hline The Guardian & Thursday October 28, 2004 \\
\hline
\end{tabular}

\section{GOVERNMENT PUBLICATIONS/REPORTS}

Federal Ministry of Sports and Social Development National Sports Festivals 1973-2006

$15^{\text {th }}$ National Sports Festival, Gateway Games Abeokuta, 2006.

\section{UNPUBLISHED WORK}

Lagos State Draft of the Sports Development Policy

Ondo State Draft of the Sports Development Policy

Oyo State Draft of the Sports Development Policy

Dr. (Mrs.) Igbokwe Philomena Ify. "A Study of the Administration of Sports Councils and Their Effects on the Performance of Athletes in Nigeria ." IOSR Journal of Sports and Physical Education (IOSR-JSPE) 4.3 (2017): 52-61. 